\title{
Konsentrasi dan Kualitas Spermatozoa Kucing Domestik (Felis catus) yang diambil dari Epididymis dan Ductus deferens setelah Preservasi pada Suhu $4^{\circ} \mathrm{C}$
}

\author{
The Concentration and the Quality of Domestic Cat's Sperm which is collected from \\ Epididymis and Ductus deferens after Preservation at $4^{\circ} \mathrm{C}$
}

\author{
Cutnya' Shaliran Nazlie ${ }^{1}$ (Alm), Iman Supriatna ${ }^{2}$, Srihadi Agungpriyono ${ }^{3}$, Arief \\ Boediono $^{3 *}$ \\ ${ }^{1} J u r u s a n$ Pendidikan MIPA FKIP Universitas Syiah Kuala, Darussalam Banda Aceh; \\ ${ }^{2}$ Departemen Klinik, Reproduksi dan Patologi \\ ${ }^{3}$ Departemen Anatomi, Fisiologi dan Farmakologi, Fakultas Kedokteran Hewan, Institut Pertanian Bogor \\ Jl. Agatis, Kampus IPB Darmaga,Bogor 16680. E-mail: ab1@cbn.net.id *Penulis untuk korespondensi
}

\begin{abstract}
The aim of this study was to evaluate the concentration, progressively motile, and percent live sperm in the various regions of epididymis and ductus deferens after preservation at $4^{\circ} \mathrm{C}$. Epididymis and ductus deferens were collected from 21 epididymis and ductus deferens of domesticated cat (Felis catus) by castration. One testicle of pair (control testicle) was analyzed at the day of castration, while the other testicle of the pair was stored at $4^{\circ} \mathrm{C}$ up to 7 days. The sperm concentration, percentage of sperm motility and live sperm were examined daily until day -7 of preservation. The sperm concentration was higher $(\mathrm{p}<0.05)$ in cauda epididymis $\left(23.99 \times 10^{6} \mathrm{sperm} / \mathrm{ml}\right)$ and ductus deferens $\left(25.42 \times 10^{6} \mathrm{sperm} / \mathrm{ml}\right)$ than caput $\left(11.51 \times 10^{6} \mathrm{sperm} / \mathrm{ml}\right)$ and corpus epididymis $\left(14.82 \times 10^{6} \mathrm{sperm} / \mathrm{ml}\right)$. The percentage of $\mathrm{sperm}$ motility and live sperm decreased $(\mathbf{p}<0.05)$ during preservation period. However, the percentage of motile $(11.33$ to $16.00 \%)$ and live $(15.05$ to $20.20 \%)$ sperm could be found in preserved epididymis and ductus deferens up to day-7. These results show that motile and live sperm can be collected from cat's epididymis and ductus deferens up to day 7 after preservation at $4^{\circ} \mathrm{C}$.
\end{abstract}

Key words : domestic cat, spermatozoa, epididymis, ductus deferens, preservation

Diterima : 04 September 2004, disetujui : 08 Agustus 2005

\section{Pendahuluan}

Indonesia mempunyai banyak hewan yang tergolong eksotis, yaitu hewan yang hanya terdapat pada lokasi tertentu saja, satu diantaranya adalah harimau Sumatera (Panthera tigris sumatrea) (Anonim, 1994). Upaya pelestarian harimau Sumatera selain dilakukan ex-situ dan in-situ, perlu alternatif lain berupa pendekatan bioteknologi reproduksi. Teknologi reproduksi saat ini sudah berkembang pesat. Sebelumnya reproduksi hewan hanya diupayakan pada hewan yang masih hidup, namun kini berkembang pemikiran untuk memanfaatkan organ reproduksi hewan yang telah mati. Pemanfaatan teknologi ini diharapkan dapat dipakai untuk mengatasi penurunan populasi hewan yang terancam punah.

Penelitian bioteknologi reproduksi pada kucing dapat digunakan sebagai hewan model untuk harimau. Banyak kesamaan antara harimau dan kucing antara lain keduanya termasuk hewan menyusui (kelas Mammalia), pemakan daging (ordo Carnivora) dan yang paling utama adalah sama-sama dari famili 
Felidae (Wright and Walters, 1980). Disamping kemampuan reproduksi tinggi (bersifat multipara), kucing mempunyai daya adaptasi baik (usaha domestikasi) dan banyak atau mudah didapat.

Viabilitas atau kelangsungan hidup spermatozoa sangat diperlukan untuk teknologi reproduksi di masa datang. Diharapkan apabila spermatozoa motil progresif tidak cukup tersedia untuk inseminasi buatan maupun produksi embrio melalui teknologi fertilisasi in vitro, maka diperlukan introduksi bioteknologi reproduksi lain berupa Intracytoplasmic Sperm Injection (ICSI). Pada teknologi ini, fertilisasi dapat terjadi dengan menginjeksi secara langsung sperma tunggal ke dalam sitoplasma oosit yang telah matang (Boediono, 2001). Lebih dari itu, apabila tidak didapatkan spermatozao motil pilihan dapat beralih kepada spermatozoa yang masih hidup walaupun immotil.

Pada hewan yang mati di alam, gonad (ovarium dan testis) sebagai sumber gamet (oosit dan spermatozoa) masih dapat dimanfaatkan beberapa waktu setelah mati. Oleh karena itu perlu dilakukan penelitian untuk mengetahui viabilitas gamet yang dikoleksi dari hewan yang sudah mati sampai periode tertentu. Pada penelitian ini pengamatan dilakukan terhadap viabilitas spermatozoa yang dikoleksi dari bagian gonad jantan berupa epididymis dan ductus deferens yang disimpan pada suhu $4^{\circ} \mathrm{C}$ sampai periode tujuh hari.

\section{Metode Penelitian}

Sampel berupa epididymis dan ductus deferens dari 21 ekor kucing lokal (Felis catus) jantan, umur 2-3 tahun setelah proses bedah kastrasi (sterilisasi jantan) yang dilakukan di Rumah Sakit Hewan atau Dokter Hewan Praktek. Epididymis dan ductus deferens dibagi menjadi tujuh kelompok perlakuan yang masing-masing kelompok terdiri atas tiga ekor kucing. Epididymis dan ductus deferens sebelah kiri dianalisis pada hari kastrasi dilakukan dan dinyatakan sebagai kontrol (H0), sedangkan epididymis dan ductus deferens sebelah kanan disimpan pada suhu $4^{\circ} \mathrm{C}$ (dalam refrigerator) sebagai perlakuan lamanya periode preservasi.

\section{Preservasi Epididymis dan Ductus deferens serta Koleksi Spermatozoa}

Epididymis dan ductus deferens (sebelah kanan) yang didapat dari proses kastrasi segera dimasukkan ke dalam kantung plastik steril berisi $25 \mathrm{ml} \mathrm{NaCl} 0,9 \%$ dan dipreservasi pada suhu $4^{\circ} \mathrm{C}$. Sampel dibedakan sesuai perlakuan periode preservasi selama satu hari $(\mathrm{H} 1)$ sampai tujuh hari $(\mathrm{H} 7)$ masing-masing tiga ulangan.

Spermatozoa dikoleksi dari seluruh bagian epididymis (caput, corpus dan cauda) dan ductus deferens. Pada epididymis, spermatozoa dikoleksi dengan metode aspirasi (sebanyak 3-6 kali) pada bagian caput, corpus dan cauda epididymis dengan menggunakan jarum ukuran 26-G yang dihubungkan dengan spuit $1 \mathrm{ml}$ dan berisi medium phosphate buffer saline (PBS, Gibco, USA) sebanyak 0,2 ml. Hasil aspirasi dimasukkan ke dalam tabung Eppendorf untuk disentrifugasi dengan kecepatan 640-G selama tiga menit. Pada ductus deferens, spermatozoa dikoleksi dengan cara membilas bagian lumen (flushing) ductus deferens (sepanjang 1,5 $\mathrm{cm}$ ) menggunakan spuit yang berisi $0,2 \mathrm{ml}$ medium PBS. Pembilasan diulang tiga kali dengan harapan semua spermatozoa yang berada pada ductus deferens akan terkoleksi.

\section{Variabel yang Diamati}

Pada penelitian ini dilakukan evaluasi terhadap konsentrasi, motilitas, dan spermatozoa hidup yang berasal dari masingmasing bagian epididymis dan ductus deferens. Konsentrasi spermatozoa diamati menggunakan kamar hitung Neubauer. Data yang disajikan merupakan konsentrasi spermatozoa rata-rata yang didapatkan dari masing-masing bagian epididymis dan ductus deferens tanpa membedakan perlakuan periode preservasi. Hal ini dilakukan karena tidak terdapat pengaruh periode preservasi terhadap konsentrasi spermatozoa yang dikoleksi dari bagian saluran kelamin yang sama.

Motilitas spermatozoa diamati dengan melihat persentase motil progresif yaitu 
spermatozoa yang bergerak lurus ke depan yang dihitung dari pengamatan 200 spermatozoa.

Viabilitas spermatozoa diamati dengan menghitung persentase spermatozoa hidup dengan metode pewarnaan differensial seperti yang dilaporkan sebelumnya oleh Saha et al. (1996) dengan beberapa modifikasi. Sampel spermatozoa dimasukkan ke dalam tabung berisi larutan bizbenzimidazole (Hoechst 33342, Sigma, USA) dan propidium iodine (Sigma, USA) masing-masing dengan konsentrasi $10 \mathrm{ug} / \mathrm{ml}$. Spermatozoa yang telah diwarnai dan diinkubasi selama 10 menit pada suhu $37^{\circ} \mathrm{C}$, diteteskan sebanyak $10 \mathrm{ul}$ di atas gelas obyek dan ditutup dengan gelas penutup. Evaluasi spermatozoa hidup dan mati dilakukan di bawah mikroskop fluorescence (Nikon, Japan). Spermatozoa hidup akan ditunjukkan dengan warna biru, sedangkan spermatozoa mati akan berwarna merah. Persentase spermatozoa hidup dihitung dari pengamatan 200 spermatozoa.

\section{Rancangan Percobaan}

Penelitian ini menggunakan rancangan acak lengkap (RAL) dua faktor (asal spermatozoa dan periode preservasi) dengan masing-masing tiga kali ulangan ditambah dengan perlakuan kontrol. Data hasil penelitian dievaluasi dengan analisa variansi dan regresi. Analisa variansi digunakan untuk mendapatkan rata-rata kualitas spermatozoa serta mengetahui ada atau tidaknya perbedaan perlakuan, sedangkan analisis regresi digunakan untuk mengetahui perubahan yang terjadi pada motilitas spermatozoa selama preservasi $\mathrm{H} 0$ sampai H7 (Sudjana, 1985) dan membahas prediksi (peramalan).

\section{Hasil dan Pembahasan}

\section{Konsentrasi Spermatozoa}

Konsentrasi spermatozoa yang dikoleksi dari bagian cauda epididymis $\left(23,99 \times 10^{6}\right.$ spermatozoa $/ \mathrm{ml}$ ) dan ductus deferens $\left(25,42 \times 10^{6} \quad\right.$ spermatozoa/ml $)$ lebih tinggi $(\mathrm{p}<0,05)$ daripada yang dikoleksi dari bagian caput $\left(11,51 \times 10^{6}\right.$ spermatozoa $\left./ \mathrm{ml}\right)$ dan corpus epididymis $\quad\left(14,82 \times 10^{6} \quad\right.$ spermatozoa/ml $)$ (Gambar 1). Hal ini sesuai dengan fungsi dari caput dan corpus epididymis sebagai saluran kelamin tempat spermatozoa diproduksi pada tubuli seminiferi dialirkan menuju cauda epididymis sebagai tempat penyimpanan spermatozoa sebelum diejakulasikan. Sedangkan pada ductus deferens, konsentrasi spermatozoa yang tinggi dimungkinkan adanya aliran spermatozoa asal cauda epididymis yang merembes ke saluran ductus deferens akibat hilangnya fungsi kontraksi otot polos setelah proses kastrasi.

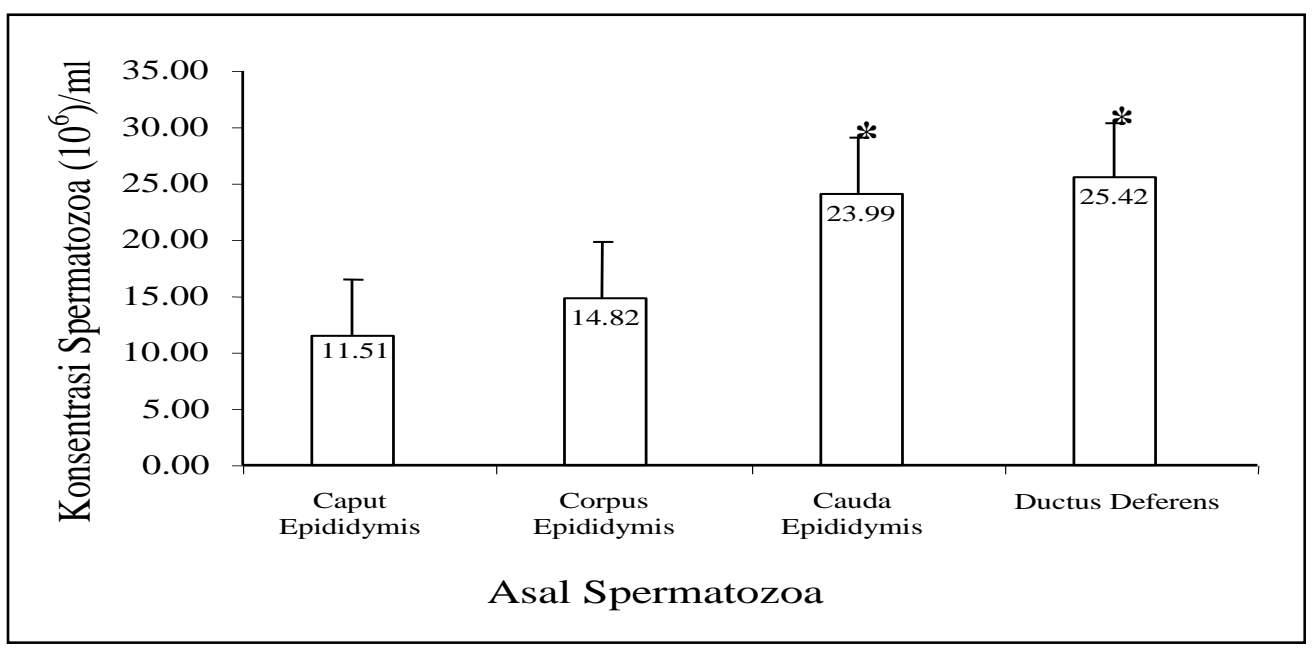

Gambar 1. Rata-rata konsentrasi spermatozoa kucing yang dikoleksi dari epididymis dan ductus deferens. 
Hafez and Hafez (2000) melaporkan bahwa konsentrasi spermatozoa cauda epididymis kucing lebih tinggi yaitu $13,00 \times 10^{8}$ spermatozoa/ml. Hal ini mungkin disebabkan periode pengambilan sampel yang berbeda, dimana kucing termasuk hewan yang mempunyai musim kawin sehingga periode pengambilan sampel juga akan mempengaruhi konsentrasi spermatozoa. Ras kucing yang berbeda dapat juga memberikan konsentrasi spermatozoa yang berbeda. Namun demikian, konsentrasi spermatozoa yang dikoleksi pada penelitian ini masih cukup tinggi untuk keperluan fertilisasi in vitro yang membutuhkan konsentrasi 2,00x $10^{6}$ spermatozoa/ml (Karja et al., 2002).

\section{Motilitas Spermatozoa}

Motilitas spermatozoa yang dikoleksi dari caput dan corpus epididymis pada $\mathrm{H} 0$ sebesar $38,00 \%$. Kondisi ini untuk selanjutnya cenderung menurun sampai preservasi $\mathrm{H} 7$ (14,00\% untuk caput epididymis dan 11,33\% untuk corpus epididymis) (Gambar 2).

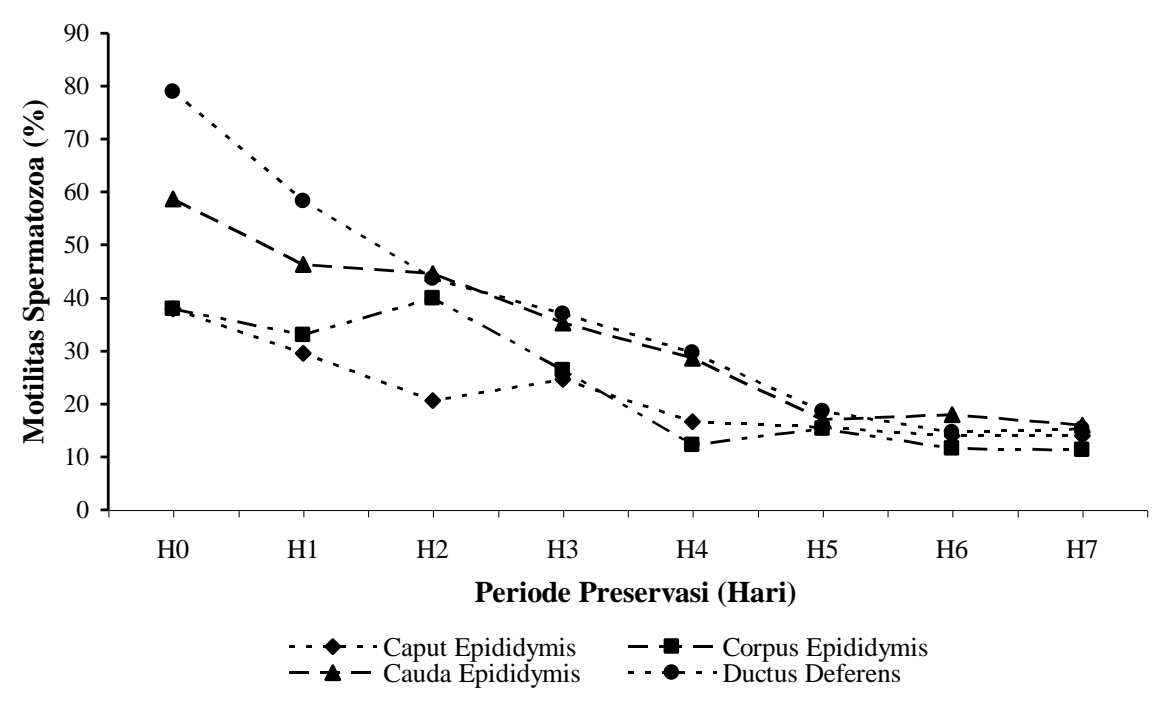

Gambar 2. Motilitas spermatozoa kucing yang dikoleksi dari epididymis dan ductus deferens setelah preservasi jaringan pada suhu $4^{\circ} \mathrm{C}$ sampai tujuh hari.

Motilitas spermatozoa yang dikoleksi dari cauda epididymis $(58,66 \%)$ pada $\mathrm{H} 0$ merupakan persentase yang paling tinggi dibandingkan dengan bagian epididymis lainnya. Setelah preservasi dalam suhu $4^{\circ} \mathrm{C}$ motilitas spermatozoa terus menurun walaupun masih didapatkan spermatozoa motil pada $\mathrm{H} 7$ sebanyak 16,00\%. Sedangkan motilitas spermatozoa yang dikoleksi dari ductus deferens pada hari kastrasi dilakukan (H0) adalah 79,00\%. Angka ini terus menurun selama periode preservasi sampai mencapai spermatozoa motil sebanyak $15,33 \%$ pada $\mathrm{H} 7$.

Motilitas spermatozoa kucing yang dikoleksi dari cauda epididymis tanpa preservasi berkisar antara 40-80\%, sementara pada caput dan corpus epididymis masing- masing 38,00\% (Axner et al., 1999). Perbedaan motilitas spermatozoa yang dilaporkan kemungkinan disebabkan karena rentang antara waktu kastrasi di Rumah Sakit Hewan dan evaluasi motilitas spermatozoa di laboratorium.Walaupun terdapat perbedaan rata-rata motilitas spermatozoa yang dikoleksi dari caput, corpus dan cauda epididymis serta ductus deferens, namun pada hari-hari terakhir penelitian (H5, H6 dan H7) tidak menunjukkan perbedaan.

Secara statistik motilitas spermatozoa yang dikoleksi dari caput epididymis, corpus epididymis, cauda epididymis dan ductus deferens kucing dari $\mathrm{H} 0$ sampai $\mathrm{H} 7$ berbeda nyata $(\mathrm{P}<0,05)$. Berdasarkan perhitungan regresi dari semua bagian epididymis dan 
ductus deferens $\mathrm{H} 0$, sampai $\mathrm{H} 7$ cenderung menurun masing-masing $3,21 \%, 4,54 \%$, $6,31 \%$, dan $8,88 \%$ per hari secara berurutan pada caput, corpus, cauda epididymis, dan ductus deferens kucing.

Preservasi epididymis dan ductus deferens pada suhu dingin $\left(4^{\circ} \mathrm{C}\right)$ bertujuan untuk menghambat metabolisme sel yang terjadi dengan harapan memperpanjang viabilitas spermatozoa, namun hal ini dapat menyebabkan penurunan motilitas spermatozoa. Selama proses preservasi, spermatozoa terus hidup dan tetap melaksanakan aktivitas dengan memanfaatkan energi hasil metabolisme yang semakin lama semakin berkurang. Selain itu hasil samping dari proses metabolisme yang berupa asam laktat berpengaruh negatif terhadap motilitas spermatozoa, menurunkan $\mathrm{pH}$ spermatozoa, dan bersifat racun yang akan merusak enzim yang berperan dalam proses metabolisme spermatozoa.

Radikal bebas dapat menurunkan frekuensi gerakan flagel, sehingga motilitas spermatozoa akan menurun (Gagnon, 1996). Diduga keadaan ini karena produksi ATP mitokondria yang rendah. Konsentrasi ATP yang rendah tidak memungkinkan protein kinase-A endogen mempertahankan proses fosforilasi aksonema protein sampai pada konsentrasi ATP yang cukup untuk menunjang motilitas. Jika konsentrasi radikal bebas di sekitar spermatozoa cukup banyak, maka lambat laun spermatozoa akan mati. Sebaliknya kalau radikal bebas sedikit, walaupun jumlah tersebut cukup untuk menghambat motilitas, ternyata spermatozoa masih mampu bangkit kembali dari pengaruh radikal bebas selama 624 jam. Informasi ini menimbulkan dugaan bahwa spermatozoa mempunyai mekanisme perbaikan diri pada kondisi dimana radikal bebas jumlahnya terbatas.

\section{Spermatozoa Hidup}

Pada H0, persentase spermatozoa hidup asal cauda epididymis $(88,75 \%)$ mencapai angka tertinggi dibandingkan dengan spermatozoa asal caput $(67,25 \%)$, corpus $(68,25 \%)$ epididymis dan ductus deferens $(78,75 \%)$. Pada proses preservasi spermatozoa pada suhu $4^{\circ} \mathrm{C}$ akan terjadi penurunan (meskipun terjadi fluktuasi) sampai pada H7, namun masih didapatkan spermatozoa hidup sebanyak 15,05\%, 17,30\%, 20,15\% dan $20,20 \%$ berturut-turut pada caput, corpus, cauda epididymis dan ductus deferens (Gambar 3).

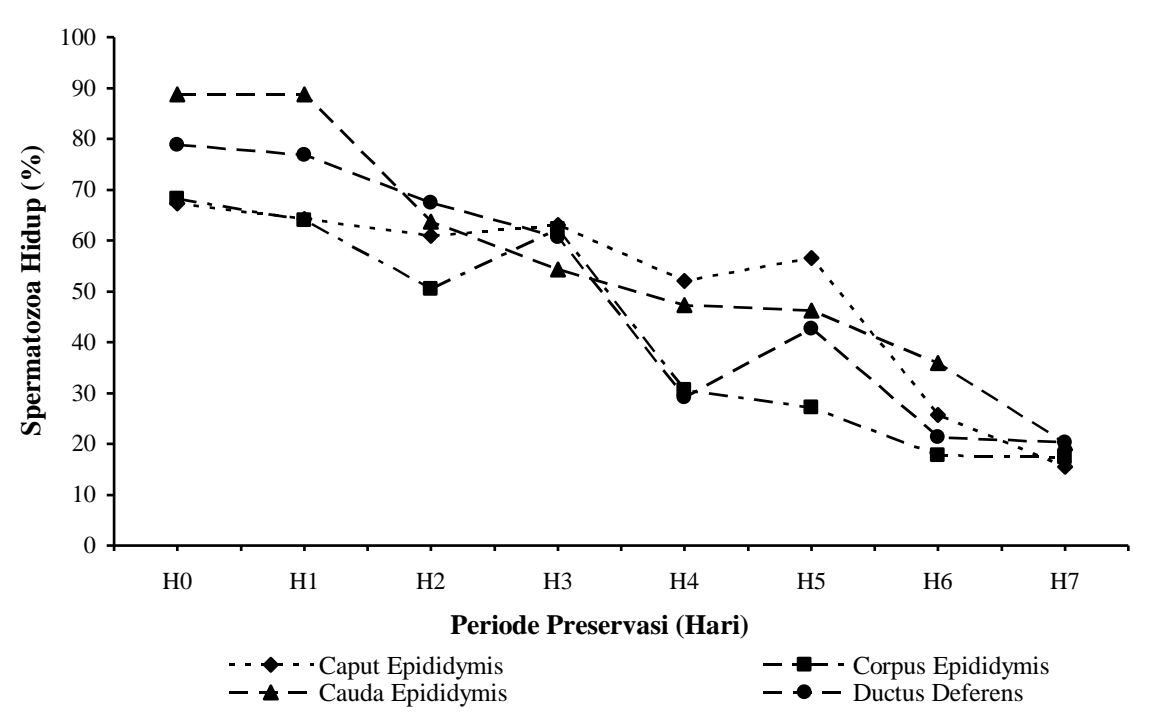

Gambar 3. Persentase spermatozoa hidup yang dikoleksi dari epididymis dan ductus deferens kucing setelah preservasi jaringan pada suhu $4^{\circ} \mathrm{C}$ sampai tujuh hari.

Dari analisis regresi semua bagian epididymis dan ductus deferens angka spermatozoa hidup cenderung menurun. Ratarata penurunan per hari berbeda-beda, untuk 
caput $6,93 \%$; corpus $9,40 \%$; cauda $9,57 \%$ dan ductus deferens $9,45 \%$. Penurunan yang paling tajam terjadi pada cauda epididymis. Meskipun pada $\mathrm{H} 0$ persentase spermatozoa hidup paling tinggi, namun pada $\mathrm{H} 7$ tidak berbeda dengan spermatozoa asal bagian epididymis yang lain dan ductus deferens. Perbandingan, porsentase spermatozoa hidup asal epididymis kambing rata-rata 92\% (Blash et al., 2000). Pola penurunan yang sama dari persentase spermatozoa hidup asal epididymis yang disimpan selama 24-96 jam pada suhu $4^{\circ} \mathrm{C}$ juga terjadi pada kuda (James et al., 2002).

\section{Kesimpulan}

Dari kajian konsentrasi dan kualitas spermatozoa kucing, didapatkan bahwa koleksi spermatozoa lebih baik dilakukan dari bagian cauda epididymis dan ductus deferens daripada dari bagian caput dan corpus epididymis. Setelah preservasi selama tujuh hari pada suhu $4^{\circ} \mathrm{C}$, masih didapatkan spermatozoa hidup dan motil pada semua bagian epididymis dan ductus deferens, walaupun dengan nilai yang cukup rendah.

\section{Ucapan Terima Kasih}

Penelitian ini sebagian didanai oleh
Proyek Riset Unggulan Terpadu IX,
Kementrian Riset dan Teknologi dan Lembaga
Ilmu Pengetahuan Indonesia (SK
No.14.07/SK/RUT/2004).

\section{Daftar Pustaka}

Axner, E., Malmqvist, M., Forsberg, L.C. and Martines, R.H. 1999 Regional Histology of the ductus epididymis in the domestic cat. J Reprod Dev, 45 (2): 151-160.

Blash, S., Melican, D. and Gavin, W. 2000. Cryopreservation of epididymal sperm obtained at necropsy from goat. Theriogenology, 54:899-905.

Boediono, A. 2001. Sperm immobilization prior to intracytoplasmic sperm injection (ICSI) and oocyte activation improve early development of microfertilized goat oocytes. Reprotech, $1: 29-34$
Anonim. 1994. Indonesian Sumatran Tiger Conservation Strategy. Panthera tigris sumatrea. Departemen Kehutanan Republik Indonesia.

Gagnon, C. 1996. Significance of reactive oxygen species formation in male infertility. The Indonesian Society of Andrology, VI ${ }^{\text {th }}$, National Congress III ${ }^{\text {rd }}$ International Symposium on New Prospecttive of Andrology in Human Reproduction. Sept. 19-24. Menado.

Hafez, B. and Hafez, E.S.E. 2000. Reproduction in Farm Animal. $7^{\text {th }}$ Ed. Philadelphia. Lea and Febiger.

James, A.N., Green, H., Hoffman, S. and Landry, A.M. 2002. Preservation of equine sperm Stored in the epididymis at $4^{\circ} \mathrm{C}$ for $24,48,72$ and 96 hours. Theriogenology, 58: 401-404.

Karja, N.W.K., Otoi, T., Murakami, M., Fahrudin, M. and Suzuki, T. 2002. In vitro maturation, fertilization and development of domestic cat oocytes recovered from ovaries collected a three stages of the reproductive cycle. Theriogenology, 57:2289-2298.

Saha, S., Rajamahendran, R., Boediono, A., Sumantri, C. and Suzuki, T. 1996. Viability of bovine blastocysts obtained after 7,8 or 9 days of culture in vitro following vitrification and one-step rehydration. Theriogenology, 46:331-343.

Sudjana. 1985. Disain dan Analisis Eksperimen.Hal: 264273. Bandung. Penerbit Tarsito.

Wright, M. and Walters, S. 1980. The Book of the Cat. 14-15, 213. London. Pan Books. 